\title{
Full steam ahead: direct steam exposure to inhibit spread of invasive aquatic macrophytes
}

\author{
Kate Crane $\mathbb{B} \cdot$ Ross N. Cuthbert • Jaimie T. A. Dick • Louise Kregting • \\ Hugh J. MacIsaac $\cdot$ Neil E. Coughlan
}

Received: 2 July 2018/ Accepted: 15 December 2018/Published online: 29 December 2018

(C) The Author(s) 2018

\begin{abstract}
Biosecurity protocols designed to prevent invader spread have become integral to invasive species management strategies. However, application of many proposed spread-prevention practices is inhibited due to low practicality, high expense, undesirable non-target effects and a lack of known efficacy. Here, we examine the use of direct steam exposure to induce substantial fragment (i.e. propagule stage) degradation of seven invasive macrophytes: Ceratophyllum demersum, Crassula helmsii, Egeria densa, Elodea canadensis, Elodea nuttallii, Lagarosiphon major and Potamogeton crispus. Each species was independently exposed to steam treatments in loose clumps of three fragments, steamed at a distance of $2-3 \mathrm{~cm}$ from the source, for varied exposure times: $10 \mathrm{~s}, 30 \mathrm{~s}, 1 \mathrm{~min}, 2 \mathrm{~min}$, and $5 \mathrm{~min}$.
\end{abstract}

Kate Crane and Neil E. Coughlan have contributed equally to this work.

\footnotetext{
K. Crane $(\bowtie) \cdot$ R. N. Cuthbert · J. T. A. Dick ·

N. E. Coughlan

Institute for Global Food Security, School of Biological

Sciences, Queen's University Belfast,

Belfast BT9 7BL, Northern Ireland, UK

e-mail: kcrane02@qub.ac.uk

R. N. Cuthbert

e-mail: rcuthbert03@qub.ac.uk

J. T. A. Dick

e-mail: j.dick@qub.ac.uk

N. E. Coughlan

e-mail: neil.coughlan.zoology@gmail.com
}

Furthermore, we develop and apply a novel degradation scale describing visual tissue biodegradation stages and/or resumption of growth for fragmentary propagules. Steam treatments were observed to be highly efficacious, with total degradation being induced by $10 \mathrm{~s}$ of direct steam exposure. This was apparent for all species following a seven day recovery period, except $C$. demersum, which took until 21 days. Conversely, control specimens displayed excellent survival and/or viability (i.e. resumption of growth). Therefore, we argue that this innovative, yet simple technique can be used to improve biosecurity practices to inhibit the spread of invasive macrophytes.

Keywords Biosecurity · Fragment degradation . Invasive species $\cdot$ Secondary dispersal $\cdot$ Spreadprevention $\cdot$ Steam clean

K. Crane · R. N. Cuthbert · J. T. A. Dick

L. Kregting · N. E. Coughlan

Queen's University Marine Laboratory, Queen's University

Belfast, Portaferry BT22 1PF, Northern Ireland, UK

e-mail: 1.kregting@qub.ac.uk

L. Kregting

School of Natural and Built Environment, Queen's

University Belfast, Belfast BT9 5BN, Northern Ireland, UK

H. J. MacIsaac

Great Lakes Institute for Environmental Research,

University of Windsor, Windsor, ON N9B 3P4, Canada

e-mail: hughm@uwindsor.ca 


\section{Introduction}

Aquatic invasive species (AIS) can adversely impact the physical, chemical and biological processes of freshwater ecosystems (Dudgeon et al. 2006; Simberloff et al. 2013; Piria et al. 2017). In particular, invasive macrophytes often represent a substantial economic burden, as large monospecific stands can inhibit recreational and commercial activities and have been shown to escalate flood frequencies (Williams et al. 2010; Lafontaine et al. 2013). Due to hydrological interconnectedness and exposure to a plethora of natural and anthropogenic vectors, freshwater systems are highly vulnerable to the introduction and spread of invasive species (Dudgeon et al. 2006; Banha and Anastácio 2015; Banha et al. 2016; Coughlan et al. 2017a). For example, an abundance of AIS have rapidly and repeatedly colonised a variety of both connected and unconnected sites, such as rivers, ponds and lakes (Santamaría 2002; Caffrey et al. 2016; Coughlan et al. 2017b; Hussner et al. 2017). Although successful overland dispersal of AIS can be facilitated by more mobile organisms (Green 2016; Coughlan et al. 2017a), the underlying mechanisms of assisted dispersal are frequently unknown (Coughlan et al. 2017c). However, anthropogenic activities such as angling, boating and the aquatic pet trade are known to have facilitated a substantial portion of AIS introductions (Johnson et al. 2001; Rothlisberger et al. 2010; Gallardo and Aldridge 2013).

Biosecurity protocols designed to prevent further invader spread have become essential to AIS management strategies (Barbour et al. 2013; Caffrey et al. 2016; Booy et al. 2017; Coughlan et al. 2017c; Cuthbert et al. 2018a, b). In particular, spreadprevention often represents the most cost effective management option, as eradication and control of established invader populations is often complex, resource-intensive and expensive (Hussner et al. 2017; Piria et al. 2017; Coughlan et al. 2018c). Moreover, once established, eradication of AIS populations is notoriously difficult (Kolar and Lodge 2001; Briski et al. 2012), with relatively few documented accounts detailing complete eradication of problematic freshwater invaders, such as invasive macrophytes (Beric and MacIsaac 2015; Hussner et al. 2017; Coughlan et al. 2018c). Accordingly, various stakeholder groups actively promote best practice biosecurity protocols such as 'Check, Clean, Dry' to reduce invader spread
(Anderson et al. 2015). Moreover, European Union (EU; Regulation 1143/2014) and United States of America (USA; Safeguarding the Nation from the Impacts of Invasive Species-amendment to Executive Order 13112) legislation requires member territories to enforce spread-prevention of damaging invaders (Coughlan et al. 2017c).

Although various invader population suppression techniques have been studied (Beric and MacIsaac 2015), there often exists only a limited understanding of the relative efficacies of proposed spread-prevention procedures (Barbour et al. 2013; Anderson et al. 2015; Piria et al. 2017; Coughlan et al. 2018a, b, c). In addition, while some methods such as hot water $\left(\geq 45^{\circ} \mathrm{C}\right.$ ) submersion appear to be both highly successful and environmentally-friendly (Anderson et al. 2015; Shannon et al. 2018), it will likely be difficult and expensive to maintain water at a high enough temperature for prolonged periods of time, especially in the field (Sebire et al. 2018). Moreover, hot water submersion will be problematic for larger equipment items, such as kayaks, canoes, boats, vehicles and trailers. Equally, chemical disinfectant treatments have also been proposed as a suitable mechanism to prevent AIS spread (Barbour et al. 2013; Cuthbert et al. 2018a, b), however, these methods are not necessarily inexpensive, or environmentally or user-friendly. Therefore, there is an urgent need to develop innovative measures that efficaciously inhibit AIS spread, while being cost-effective, easily applied, and ideally having negligible non-target effects.

Many invasive aquatic macrophytes predominantly reproduce and spread by vegetative propagation, particularly through vegetative fragments (Umetsu et al. 2012; Li et al. 2015; Redekop et al. 2016). Although the dispersal potential of plant fragments (i.e. propagules) will vary among species, exceptionally small ( $\leq 23 \mathrm{~mm}$; Coughlan et al. 2018b) and even single node stem fragments can display substantial regeneration of biomass (Bickel 2015; Heidbüchel et al. 2016). Fragmentary propagule creation can occur by either self-induced autofragmentation, or allofragmentation as a result of physical disturbance (Riis et al. 2009; Heidbüchel et al. 2016). This division of aquatic macrophytes into fragmentary propagules can be facilitated by water currents, herbivory, and anthropogenic activities (Johnson et al. 2001; Rothlisberger et al. 2010; Bakker et al. 2016; Hussner et al. 2017). Although tolerance to desiccation will be a 
limiting factor for successful dispersal (Bruckerhoff et al. 2015; Evans et al. 2011; Bickel 2015; Coughlan et al. 2018b), equipment such as fishing nets, watercraft, boat trailers, and towing vehicles continuously facilitate invader overland transport (Johnson et al. 2001; Rothlisberger et al. 2010). Moreover, although compliance with current best practice biosecurity protocols likely reduces invader spread, visual inspection of some sections of equipment may not be possible, and decontamination methods (e.g. brushing, scraping, high pressure washing, hand-removal) will not necessarily result in complete invader propagule removal or mortality (Rothlisberger et al. 2010). In addition, desiccation induced mortality by enacting extended drying times prior to visiting uninvaded waterways may not be feasible (Coughlan et al. 2018b; Sutcliffe et al. 2018), as many recreational water users rapidly and repeatedly travel short distances between different freshwater sites, and often rapidly travel long-distances (e.g. 260-9500 km) between multiple sites (Anderson et al. 2014; De Ventura et al. 2016). For example, De Ventura et al. (2016) found that, when transported overland, $67 \%$ of all moored boats are subsequently relaunched within less than two days. Consequently, the risk of continued invader spread remains highly possible, even with adherence to current decontamination protocols.

Accordingly, quantifying survival and viability (i.e. resumption of growth) for plant fragments postexposure to biosecurity treatments will improve knowledge of spread-prevention techniques to decontaminate equipment and inform correct disposal of weeds following removal from infested sites (Barnes et al. 2013; Bruckerhoff et al. 2015; Hussner et al. 2017; Coughlan et al. 2018b). In this study, we examined the efficacy of direct steam exposure to reduce the secondary spread of fragmentary propagules of seven invasive macrophytes. Although limited research has examined the use of steam for the suppression of unwanted terrestrial weed species (Bond and Grundy 2001; Rask and Kristoffersen 2007), the application of steam as a mechanism to control freshwater invasive macrophytes has not previously been investigated. Recently, however, Coughlan et al. (2018a) demonstrated that thirty seconds of direct steam exposure can cause complete mortality of Asian clams Corbicula fluminea O.F.Müll. Accordingly, it is argued, that steam applications could potentially facilitate improved biosecurity protocols to prevent the further spread of prolific freshwater invaders. In addition, we further develop the novel fragment degradation scale recently proposed by Cuthbert et al. (2018a). The scale facilitates the scoring of fragments based on a simple assessment of visual tissue biodegradation stages and/or resumption of growth. Here, we hypothesised that direct steam exposure will induce substantial fragment degradation, or even mortality, dependent on exposure time.

\section{Methods}

Survival of invasive macrophyte fragmentary propagules to steam exposure was examined for seven prolific invaders: Ceratophyllum demersum L., Crassula helmsii (Kirk) Cockayne, Egeria densa (Planch.) Casp., Elodea canadensis Michx., Elodea nuttallii (Planch.) H. St. John, Lagarosiphon major (Ridl.) Moss, and Potamogeton crispus L. (Table 1). All selected species can asexually reproduce via vegetative fragments, which are frequently observed to be transferred by a variety of anthropogenic vectors such as watercraft, boat trailers and vehicles (see www. cabi.org/isc/ for further species-specific information).

Source sites, cultivation and preparation

Each species was collected locally throughout Northern Ireland from a variety of lakes and ponds (Table 1). Species were separately maintained in the laboratory within aerated aquaria, filled with locally sourced pond water (Lough Cowey: $54^{\circ} 24^{\prime} 41.79^{\prime \prime} \mathrm{N}$; $\left.5^{\circ} 32^{\prime} 25.96^{\prime \prime} \mathrm{W}\right)$. Light of 200-250 $\mu \mathrm{mol} \mathrm{m} \mathrm{m}^{-2} \mathrm{~s}^{-1}$ was supplied by cool white fluorescent lamps under a 16-h light and 8-h darkness regime. Temperature was maintained at circa $13{ }^{\circ} \mathrm{C}$. Water was exchanged on a weekly basis. Species displayed excellent survival and sustained growth during a cultivation period of 3 months. All waste invasive plant material was destroyed by autoclaving.

Apical fragments were harvested from mature plants. Where possible, fragments were cut from unbranched sections of stem; however, if present, axillary side shoots and turions were left intact. For most species, fragment length was based on the number of nodes, with specimens cut immediately below the final node (Table 2). However, if plants lacked distinct nodes, an arbitrary length was chosen 
Table 1 Study species, source site locations and invaded range

\begin{tabular}{|c|c|c|c|}
\hline Species & Common name & Source site & Non-native range \\
\hline $\begin{array}{l}\text { Ceratophyllum demersum } \\
\text { L. }\end{array}$ & Coontail & $\begin{array}{l}\text { Lower Lough Erne } \\
54^{\circ} 25^{\prime} 25.7^{\prime \prime} \mathrm{N} \\
7^{\circ} 41^{\prime} 39.2^{\prime \prime} \mathrm{W}\end{array}$ & New Zealand, invasive in native range \\
\hline $\begin{array}{l}\text { Crassula helmsii (Kirk) } \\
\text { Cockayne }\end{array}$ & $\begin{array}{l}\text { Australian swamp } \\
\text { stonecrop }\end{array}$ & $\begin{array}{l}\text { Lough Beg } \\
54^{\circ} 47^{\prime} 28.6^{\prime \prime} \mathrm{N} ; \\
6^{\circ} 28^{\prime} 27.1^{\prime \prime} \mathrm{W}\end{array}$ & Europe, North America, invasive in native range \\
\hline $\begin{array}{l}\text { Egeria densa (Planch.) } \\
\text { Casp. }\end{array}$ & Leafy elodea & $\begin{array}{l}\text { Artificial Pond } \\
\text { Dominican College } \\
\text { Portstewart } \\
55^{\circ} 10^{\prime} 54.1^{\prime \prime} \mathrm{N} ; \\
6^{\circ} 43^{\prime} 18.3^{\prime \prime} \mathrm{W}\end{array}$ & $\begin{array}{l}\text { Europe, North America, Central America, Caribbean, } \\
\text { Oceania }\end{array}$ \\
\hline Elodea canadensis Michx. & $\begin{array}{l}\text { Canadian } \\
\text { waterweed }\end{array}$ & $\begin{array}{l}\text { Mill Pond } \\
\text { Tully Mill } \\
54^{\circ} 15^{\prime} 32.34^{\prime \prime} \mathrm{N} ; \\
7^{\circ} 42^{\prime} 50.88^{\prime \prime} \mathrm{W}\end{array}$ & $\begin{array}{l}\text { South America, Europe, Africa, Asia, Oceania, } \\
\text { invasive in native range }\end{array}$ \\
\hline $\begin{array}{l}\text { Elodea nuttallii (Planch.) } \\
\text { H. St. John }\end{array}$ & Nuttall's waterweed & $\begin{array}{l}\text { Upper Lough Erne } \\
\text { Knockninny } \\
54^{\circ} 13^{\prime} 50.6^{\prime \prime} \mathrm{N} \\
7^{\circ} 34^{\prime} 14.2^{\prime \prime} \mathrm{W}\end{array}$ & Europe, Asia \\
\hline $\begin{array}{l}\text { Lagarosiphon major } \\
\text { (Ridl.) Moss }\end{array}$ & African elodea & $\begin{array}{l}\text { Artificial Pond } \\
\text { Portadown Golf Club } \\
54^{\circ} 24^{\prime} 14.6^{\prime \prime} \mathrm{N} \text {; } \\
6^{\circ} 24^{\prime} 51.3^{\prime \prime} \mathrm{W}\end{array}$ & $\begin{array}{l}\text { Europe, Australia, New Zealand, potentially invasive } \\
\text { in native range }\end{array}$ \\
\hline Potamogeton crispus L. & $\begin{array}{l}\text { Curly-leaf } \\
\text { pondweed }\end{array}$ & $\begin{array}{l}\text { Mill Pond } \\
\text { Tully Mill } \\
54^{\circ} 15^{\prime} 32.34^{\prime \prime} \mathrm{N} ; \\
7^{\circ} 42^{\prime} 50.88^{\prime \prime} \mathrm{W}\end{array}$ & $\begin{array}{l}\text { North America, New Zealand, Fiji, South America, } \\
\text { invasive in native range }\end{array}$ \\
\hline
\end{tabular}

See www.cabi.org/isc/ for further species specific information

based on available plant material ( $L$. major, $60 \pm 0 \mathrm{~mm}$ and $C$. demersum, $35 \pm 0.6 \mathrm{~mm}$ ). Fragments were harvested as required and briefly maintained $(<30 \mathrm{~min})$ in de-chlorinated tap-water prior to experimental use. Plant fragments were randomly selected from these holding aquaria and excess liquid was gently removed by manually spinning individual fragments, 10 times in both directions, within a handheld centrifugal spinner.

\section{Experimental steam exposure}

Each species was then independently exposed to steam treatments. Groups of three fragments, each placed in parallel on a flat plastic board as a loose clump, were directly exposed to a continuous jet of steam at $\geq 100{ }^{\circ} \mathrm{C}\left(\right.$ Bissell $^{\circledR}$ Steam Shot Handheld Steam
Cleaner) at a distance of $2-3 \mathrm{~cm}$ from the spout of the device for: $10 \mathrm{~s} ; 30 \mathrm{~s} ; 1 \mathrm{~min} ; 2 \mathrm{~min}$, and $5 \mathrm{~min}$ (Table 2; $n=3$ replicates for each experimental group). The jet of steam was manoeuvred along the entire length of the fragments for the duration of the assigned exposure time, repeatedly moving in both directions. Due to their relatively large size, fragments of $P$. crispus were each steamed individually, with three fragments per experimental group, replicated in triplicate overall. Control groups were allowed to air dry for the maximum 5 min treatment period. Post exposure, fragments were allowed to cool for a $10 \mathrm{~min}$ period and were then returned to vessels containing $200 \mathrm{ml}$ of de-chlorinated tap-water. Fragment tissue degradation and resumption of growth were assessed following a 7 day recovery period, and in the case of C. demersum, also at 14 and 21 days, using a novel 
Table 2 Summation of species mean fragmentary propagule lengths and weights, treatment durations $(n=3)$ and degradation assessment points (i.e. recovery days post exposure) for each focal species

\begin{tabular}{llccl}
\hline Species & Node count & Mean $( \pm$ SE) length $\mathrm{mm}$ & Mean $( \pm$ SE) weight $\mathrm{g}$ & Assessment point \\
\hline Ceratophyllum demersum & - & $35.0 \pm 0.6$ & $1.1 \pm 0.05$ & $7,14,21$ days \\
Crassula helmsii & 15 & $69.5 \pm 1.7$ & $0.11 \pm 0.01$ & 7 days \\
Egeria densa & 10 & $86.7 \pm 2.5$ & $0.63 \pm 0.02$ & 7 days \\
Elodea canadensis & 20 & $100 \pm 10.0$ & $0.27 \pm 0.01$ & 7 days \\
Elodea nuttallii & 20 & $100 \pm 10.0$ & $0.17 \pm 0.01$ & 7 days \\
Lagarosiphon major & - & $60.0 \pm 0$ & $0.51 \pm 0.02$ & 7 days \\
Potamogeton crispus & 6 & $185.6 \pm 4.7$ & $0.86 \pm 0.06$ & 7 days
\end{tabular}

Treatments of direct steam exposure for $10 \mathrm{~s}, 30 \mathrm{~s}, 1 \mathrm{~min}, 2 \mathrm{~min}$ and 5 min were employed, with control samples air-dried for a 5 min period

degradation scale (Table 3). A longer observation period of up to 21 days was required for $C$. demersum, which displayed a slower visible rate of fragment disintegration in relation to the other examined species. The eleven-point degradation scale (0-10, inclusive), allows for visual estimation of plant degradation and/or viability. Scores of 0-4 accommodate various incremental levels of plant tissue degradation but with resumption of new growth. A score of 5 indicates no deterioration of the plant tissues (other than unavoidable minimal degradation of the fragmentary site) or resumption of growth. Scores of 6-10 denote plant tissue deterioration up to and including complete degradation (i.e. mortality), with no new growth. The standard conditions for fragmentary growth were $\operatorname{circa} 18{ }^{\circ} \mathrm{C}$, with 16:8 light-dark regime at a light intensity of $200-250 \mu \mathrm{mol} \mathrm{m} \mathrm{m}^{-2} \mathrm{~s}^{-1}$, supplied by cool white fluorescent lamps. Due to evaporation, vessels were topped-up every 2-3 days with de-chlorinated tap-water from an aerated source.

\section{Statistical analyses}

As three fragments were contained within each individual replicate, in order to maximise consideration for potential plant viability in analyses, we selected the single most viable fragment score (i.e. the lowest score observed) from each group as a

Table 3 Degradation scale describing visual tissue biodegradation stages and/or resumption of growth for aquatic macrophyte fragmentary propagules

\begin{tabular}{cc}
\hline Score & Description \\
\hline 10 & Complete degradation. \\
9 & No new shoot and/or root growth present with more than or equal to $90 \%$ stem degradation. \\
8 & No new shoot and/or root growth present with more than or equal to $50 \%$ stem degradation. \\
7 & No new shoot and/or root growth present with all leaved exhibiting paling or browning. \\
6 & No new shoot and/or root growth present with paling or browning affecting any leaves. \\
\hline 5 & No new shoot and/or root growth present with degradation at fragmentation site. \\
\hline 4 & New shoot and/or root growth present with more than or equal to $90 \%$ stem degradation. \\
3 & New shoot and/or root growth present with more than or equal to $50 \%$ stem degradation. \\
2 & New shoot and/or root growth present with all leaves exhibiting paling or browning. \\
1 & New shoot and/or root growth present with paling or browning affecting any leaves. \\
0 & New shoot and/or root growth present with degradation at fragmentation site. \\
\hline
\end{tabular}

Colour codes relate to the graphical representation of result in Fig. 1 

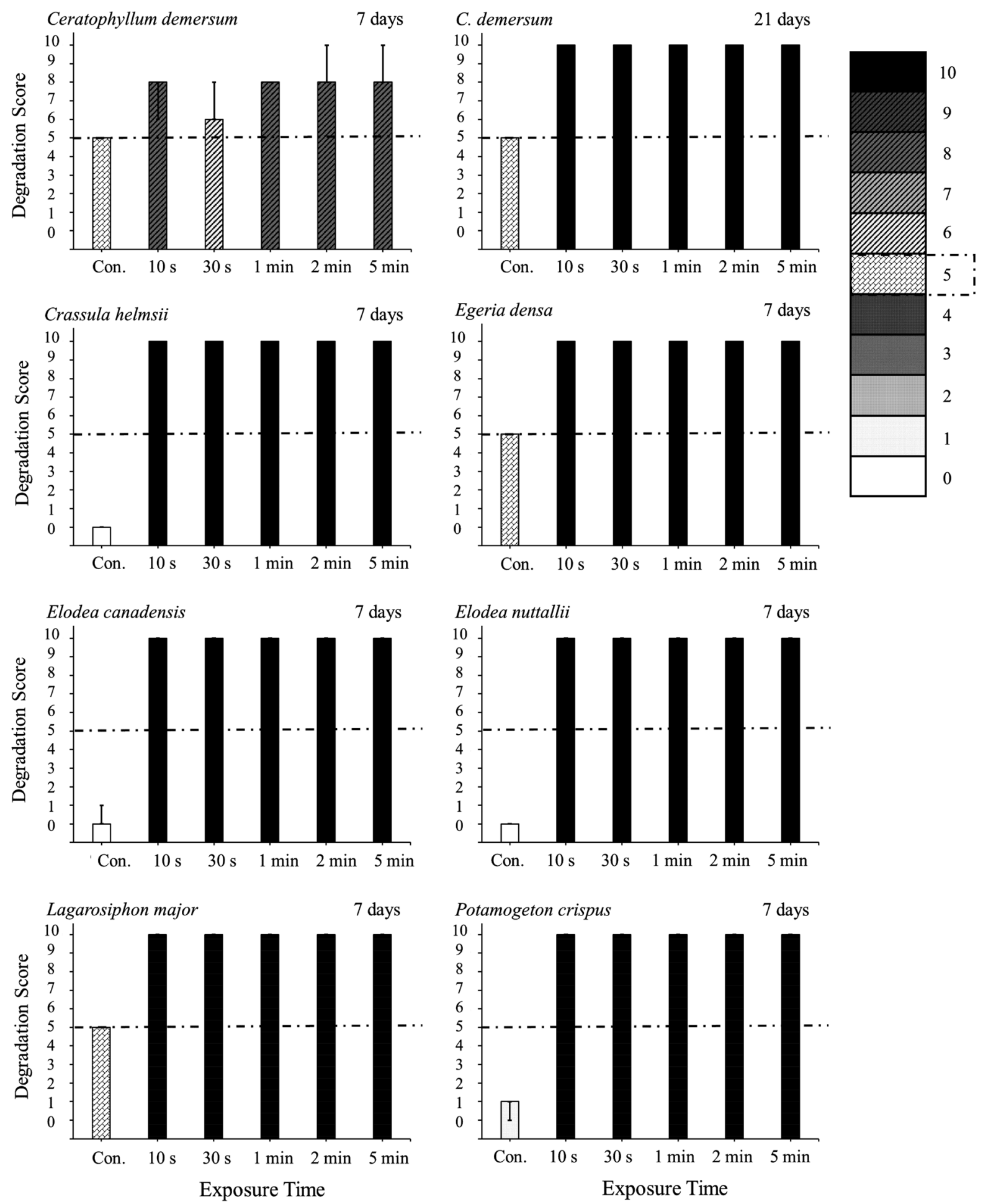
४Fig. 1 Median degradation score describing visual biodegradation stages and/or resumption of growth for aquatic macrophyte fragmentary propagules at 7 or 21 days post exposure to direct steam treatments $(n=3)$. Bars signify minimum and maximum scores attained. The dashed line highlights a score of 5 , whereby no meaningful deterioration of the plant tissues or resumption of growth has occurred. Scores of 0-4 portray incremental levels of degradation, while noting the presence of sustained viability. Scores of 6-10 denote plant tissue deterioration stages which lack of viability in relation to the resumption of new growth. See Table 3 for description of the score categories

nominated data point. Statistical analyses were performed using R v3.4.2 ( $\mathrm{R}$ Core Team 2017). We analysed the final scaled tissue degradation scores for each plant species, obtained at 7 or 21 days, as ordinal data using Kruskal-Wallis rank sum tests with respect to 'steam exposure time' i.e. $10 \mathrm{~s} ; 30 \mathrm{~s} ; 1 \mathrm{~min} ; 2 \mathrm{~min}$, and $5 \mathrm{~min}$, and this included the control groups.

\section{Results}

Overall, treatment with steam significantly induced fragment degradation (for all plant species $\chi^{2}=17.00$, $d f=5, \quad P=0.005)$. Fragmentary propagules for almost all of the examined species displayed total degradation (i.e. a score of 10) at 7 days post-exposure to steam treatments lasting $10 \mathrm{~s}$ or longer (Fig. 1). Ceratophyllum demersum fragment degradation increased incrementally between days 7, 14 and 21 (Fig. 1). At 14 days, C. demersum had not yet displayed complete degradation. At this time, $10 \mathrm{~s}$, $30 \mathrm{~s}$ and 1 min treatments scored a median degradation score of 9, while fragments exposed to $2 \mathrm{~min}$ steam treatments scored 10. Final confirmation of $C$. demersum mortality was observed at 21 days for steam exposure durations of $10 \mathrm{~s}$ or longer (Fig. 1).

Control specimens for all species displayed survival (i.e. a score of 5, with expected minimal degradation at the site of stem fragmentation only), and in most cases viability in relation to resumption of growth (score $\leq 4)$. After 7 days controls of $C$. helmsii, E. canadensis and E. nuttallii showed no decline and scored 0 on the degradation scale, having new shoot and/or root growth present with only minor degradation at the fragmentation site. Controls of $C$. demersum, E. densa and L. major also showed no signs of decline (with expected minimal degradation at site of stem fragmentation) and, despite not having resumed growth, appeared healthy. P. crispus displayed minor browning on some leaves but had resumed growth.

\section{Discussion}

Direct steam exposure lasting $10 \mathrm{~s}$ achieved a score of 10 on the degradation scale, whereby the complete degradation of fragmentary propagules was achieved. Complete degradation was observed for all examined aquatic macrophytes following a 7 day assessment period, with the exception of $C$. demersum which took up to 21 days to display full degradation. The slower visual degradation of $C$. demersum was likely due its more rigid stem morphology, relative to the other examined species. For all species, given the total lack of viability shown following the 7 day recovery period, it appears that steam treatments caused rapid, if not immediate, mortality of the specimens. Accordingly, our results indicate that direct steam exposure is a highly efficacious method of inducing propagule mortality. Although the mechanical stress of stem fragmentation may have contributed to increased degradation, we consider this unlikely given the complete survival (score $\leq 5$ ) and, in most cases, the resumption of growth (score $\leq 4$ ) was observed across control samples. Moreover, fragmentary propagules with apical tips generally have greater colonization and regeneration abilities, and higher growth rates than fragments which lack an apical tip (Riis et al. 2009; Umetsu et al. 2012). Therefore, as the present study only examined fragments with apical tips, it appears that brief steam application will further reduce invasive macrophyte spread and induce mortality of fragmentary propagules.

Although small sized propagules can result in enhanced species spread, larger fragments will likely retain a greater capacity for survival (Hoffmann et al. 2014; Kuntz et al. 2014; Li et al. 2015; Redekop et al. 2016). Here, we examined relatively large fragmentary propagules given that larger fragments are likely to have a greater capacity for growth resumption (Jiang et al. 2009) and mitigate lateral growth reductions driven by apical dominance (Cline 1991). However, the size of plant propagules examined in the present study is still likely within the range capable of 
surviving transportation by human-mediated vectors (Barrat-Segretain et al. 1998; Coughlan et al. 2018b). It is plausible that longer steam applications may be required for larger fragments, for species which display a relatively thicker fragmentary mid-stem, and those which have more robust emergent life stages. Moreover, large clumps of plant material, such as longer stems coiled into several layers, may display increased resistance to steam applications. This potential resistance to direct steam exposure follows general physical principles, as larger clumps should have a lower surface area to volume ratio than single stems, and thus lower evaporative loss (Bruckerhoff et al. 2015). Therefore, length of exposure time needed to induce complete mortality in such scenarios requires confirmation.

Previously, Rothlisberger et al. (2010) observed that visual inspection and hand removal can reduce adhering macrophytes on trailered boats by $88 \% \pm 5 \% \quad($ mean $\pm \mathrm{SE})$, while decontamination using high-pressure and low-pressure washing resulted in macrophyte removal rates of $83 \% \pm 4 \%$ and $62 \% \pm 3 \%$, respectively. However, these commonly promoted and utilised methods of decontamination did not result in the complete removal of macrophyte biomass, nor likely induce complete mortality of viable propagules. Interestingly, immersion in hot water $\left(45^{\circ} \mathrm{C}\right)$ for $15 \mathrm{~min}$ can induce up to $100 \%$ mortality of some AIS (Anderson et al. 2015). However, this method only induced $90 \%$ mortality for specimens of $C$. helmsii, while our application of direct steam exposure rapidly induced $100 \%$ mortality at $10 \mathrm{~s}$ exposure. Shorter submergence times in higher water temperatures $\left(\geq 50^{\circ} \mathrm{C}\right)$ can also result in substantial, if not complete AIS mortality (Shannon et al. 2018). While hot water at $45{ }^{\circ} \mathrm{C}$ represents a safe and simple decontamination method, application of steam should present no greater risk than the use of high-pressure washers if appropriate care is taken with users being risk aware. In particular, while the apparent excellent potential of hot water should be further explored, steam applications could provide for effective biosecurity when immersion into hot water may not be feasible, such as large nets and watercraft.

Although previous studies have proposed the use of chemical biosecurity protocols (Barbour et al. 2013; Cuthbert et al. 2018a), the simple non-chemical method of steam applications may provide for an effective, efficient, environmentally-friendly and relatively inexpensive method of spread-prevention. Equally, steam treatments represent a negligible environmental hazard in relation to non-target effects, which can occur through spillage or mismanagement of chemical treatments. Accordingly, additional research to further examine the efficacy of steam to induce mortality for all life stages of a wide range of current, emerging and potential AIS would be highly beneficial. In particular, understanding the susceptibility of juvenile stages (e.g. seeds, spores, eggs, ephippia, gemmules, statoblasts, cysts or veligers) to steam treatments is an essential aspect of further research. Many of these microscopic juvenile life stages can be frequently dispersed, difficult to detect and often remain impervious to suboptimal conditions and resistant to desiccation for long periods of time (Banha et al. 2016; Coughlan et al. 2017a). Moreover, determination of the efficacy of steam treatments to prevent the continued worldwide spread of damaging aquatic parasites and pathogens, such as inter alia the salmon fluke, Gyrodactylus salaris (Sandodden et al. 2018), the crayfish plague, Aphanomyces astaci (Svoboda et al. 2017), and amphibian ranaviruses (Price et al. 2017), is urgently required. Many of these organisms can disperse between non-hydrologically connected watercourses, with anthropogenic activities being linked to their continued spread and persistence (Price et al. 2017; Sandodden et al. 2018; Svoboda et al. 2017).

To ascertain if biosecurity steam treatments may provide for a new method of AIS spread-prevention, trials evaluating the efficacy of in situ steam treatments to clean and decontaminate equipment which can transport AIS (e.g. nets, boats) would also be informative. Equally, subsequent assessment of survival and viability for any AIS removed from equipment by steam treatment would also be worthwhile. Moreover, the use of innovative biosecurity methods, such as steam treatments, to prevent the spread and aid removal of invasive marine biofouling organisms warrants examination. Globally, biofouling by invasive marine organism remains a problematic issue. Although, international regulations seek to impede the transfer biofouling organisms by the shipping industry, recreational maritime yachts, which often travel intra-regionally between marinas, remain substantial and poorly regulated vectors of biofouling invaders (Peters et al. 2017). 
The promising results presented here suggest direct steam applications could be used to enhance biosecurity protocols to prevent the further spread of invasive aquatic macrophytes. As compliance with best practice protocols can be low (Anderson et al. 2014), with stakeholders often experiencing a lack of clear guidance (Sutcliffe et al. 2018), increased emphasis should be allocated to the systematic examination of equipment, followed by removal of adhering materials using only the most efficacious biosecurity treatments (Coughlan et al. 2018b). Installation of both industrial or household steam cleaning devices at frequently visited areas and points of entry (e.g. angling stations, harbours and boat ramps) may facilitate utilisation of a simple, environmentally-friendly, cost-effective, but a highly efficacious biosecurity protocol. These steam decontamination facilities could mimic the design of car-wash stations (Coughlan et al. 2018a), and could potentially be operated by a trained attendant, be selfservice, or automated for vehicles and trailered boats to pass through. In addition, as industrial steam cleaners can produce large volumes of steam, at higher pressures and temperatures than household steamers (e.g., 10-12 Bar; $\geq 180{ }^{\circ} \mathrm{C}$ ), these devices are more likely to facilitate the improved decontamination of large and more structurally complex equipment, such as boats and trailers. Longer device lances or flexible tubes could also be used to deliver steam applications into structural areas difficult to decontaminate by using conventional biosecurity methods alone. Increased steam temperature and pressure may also provide for efficacious decontamination of equipment at greater distances from the spout, beyond the 2-3 cm distance examined in this study. However, further research is required to ascertain minimum steam exposure times, distance from spout, practicality of in-field applications, and the effect of steam on larger fragmentary clumps with greater biomass.

Overall, steam applications present a promising decontamination method that has potential to improve biosecurity protocols for the spread-prevention for a range of 'hitch-hiking' AIS, such as macrophytes, amphipod crustaceans, bivalves and gastropods (Coughlan et al. 2018a). Accordingly, further examination, promotion and adoption of steam cleaning by biosecurity campaigns, stakeholder groups, and practitioners should be encouraged and incorporated into relevant legislation, with subsequent enforcement in relation to all water users.
Acknowledgements $\mathrm{KC}$ is supported through contributions from Queen's University Belfast, the University of Windsor, McGill University and Waterways Ireland. RNC acknowledges support from Department for the Economy (DfE), Northern Ireland. JTAD and NEC are supported by the Irish EPA research grant 2015-NC-MS-4. We also thank NERC. We particularly thank Mánus Cunningham, Dr Lawrence Eagling, Simon Exley, Emma Gorman and James Dickey for their helpful contributions.

Author contributions $\mathrm{KC}$ and NEC proposed the study; KC, NEC and RNC designed the experiment; KC and NEC conducted the experiment; RNC performed data analysis; all authors contributed to writing the manuscript, which was led by NEC.

Open Access This article is distributed under the terms of the Creative Commons Attribution 4.0 International License (http:// creativecommons.org/licenses/by/4.0/), which permits unrestricted use, distribution, and reproduction in any medium, provided you give appropriate credit to the original author(s) and the source, provide a link to the Creative Commons license, and indicate if changes were made.

\section{References}

Anderson LG, White PCL, Stebbing PD, Stentiford GD, Dunn AM (2014) Biosecurity and vector behaviour: evaluating the potential threat posed by anglers and canoeists as pathways for the spread of invasive non-native species and pathogens. PLoS ONE 9:e92788. https://doi.org/10.1371/ journal.pone.0092788

Anderson LG, Dunn AM, Rosewarne PJ, Stebbing PD (2015) Invaders in hot water: a simple decontamination method to prevent the accidental spread of aquatic invasive non-native species. Biol Invasions 17:2287-2297

Bakker ES, Wood KA, Pagès JF, Veen GF, Christianen MJA, Santamaría L, Nolet BA, Hilt S (2016) Herbivory on freshwater and marine macrophytes: a review and perspective. Aquat Bot 135:18-36

Banha F, Anastácio PM (2015) Live bait capture and crayfish trapping as potential vectors for freshwater invasive fauna. Limnologica 51:63-69

Banha F, Gimeno I, Lanao M, Touya V, Durán C, Peribáñez M, Anastácio P (2016) The role of waterfowl and fishing gear on zebra mussel larvae dispersal. Biol Invasions 18:115-125

Barbour JH, McMenamin S, Dick JTA, Alexander ME, Caffrey JM (2013) Biosecurity measures to reduce the spread of the invasive freshwater Asian clam, Corbicula fluminea (Müller, 1774). Manag Biol Invasion 4:219-230

Barnes MA, Jerde CL, Keller D, Chadderton WL, Howeth JG, Lodge DM (2013) Viability of aquatic plant fragments following desiccation. Invasive Plant Sci Manag 6:320-325

Barrat-Segretain MH, Bornette G, Hering-Vilas-Bôas A (1998) Comparative abilities of vegetative regeneration among 
aquatic plants growing in disturbed habitats. Aquat Bot 60:201-211

Beric B, MacIsaac HJ (2015) Determinants of rapid response success for alien invasive species in aquatic ecosystems. Biol Invasions 17:3327-3335

Bickel TO (2015) A boat hitchhiker's guide to survival: Cabomba caroliniana desiccation resistance and survival ability. Hydrobiologia 746:123-134

Bond W, Grundy AC (2001) Non-chemical weed management in organic farming systems. Weed Res 41:383-405

Booy O, Mill AC, Roy HE, Hiley A, Moore N, Robertson P, Baker S, Brazier M, Bue M, Bullock R, Campbell S, Eyre D, Foster J, Hatton-Ellis M, Long J, Macadam C, Morrison-Bell C, Mumford J, Newman J, Parrott D, Payne R, Renals T, Rodgers E, Spencer M, Stebbing P, Sutton-Croft M, Walker KJ, Ward A, Whittaker S, Wyn G (2017) Risk management to prioritise the eradication of new and emerging invasive non-native species. Biol Invasions 19:2401-2417

Briski E, Wiley CJ, Bailey SA (2012) Role of domestic shipping in the introduction or secondary spread of nonindigenous species: biological invasions within the Laurentian Great Lakes. J Appl Ecol 49:1124-1130

Bruckerhoff L, Havel J, Knight S (2015) Survival of invasive aquatic plants after air exposure and implications for dispersal by recreational boats. Hydrobiologia 746:113-121

Caffrey JM, Dick JTA, Lucy FE, Davis E, Niven A, Coughlan NE (2016) First record of the Asian clam Corbicula fluminea (Müller, 1774) (Bivalvia, Cyrenidae) in Northern Ireland. BioInvasions Rec 5:239-244

Cline MG (1991) Apical dominance. Bot Rev 57:318-358

Coughlan NE, Kelly TC, Davenport J, Jansen MAK (2017a) Up, up and away: bird-mediated ectozoochorous dispersal between aquatic environments. Freshw Biol 62:631-648

Coughlan NE, Kelly TC, Jansen MAK (2017b) "Step by step": high frequency short-distance epizoochorous dispersal of aquatic macrophytes. Biol Invasions 19:625-634

Coughlan NE, Stevens AL, Kelly TC, Dick JTA, Jansen MAK (2017c) Zoochorous dispersal of freshwater bivalves: an overlooked vector in biological invasions? Knowl Manag Aquat Ecosyst 418:42. https://doi.org/10.1051/kmae/ 2017037

Coughlan NE, Cuthbert RN, Dickey JWE, Crane K, Caffrey JM, Lucy FE, Davis E, Dick JTA (2018a) Better biosecurity: spread-prevention of the invasive Asian clam, Corbicula fluminea (Müller, 1774). Manag Biol Invasion. (In Press)

Coughlan NE, Cuthbert RN, Kelly TC, Jansen MAK (2018b) Parched plants: survival and viability of invasive aquatic macrophytes following exposure to various desiccation regimes. Aquat Bot 150:9-15

Coughlan NE, Walsh DA, Caffrey JM, Davis E, Lucy FE, Cuthbert RN, Dick JTA (2018c) Cold as Ice: a novel eradication and control method for invasive Asian clam, Corbicula fluminea, using pelleted dry ice. Manag Biol Invasion 9:463-474

Cuthbert RN, Coughlan NE, Crane K, Caffrey JM, MacIsaac HJ, Dick JTA (2018a) A dip or a dab: assessing the efficacy of Virasure ${ }^{\circledR}$ Aquatic disinfectant to reduce secondary spread of the invasive curly waterweed Lagarosiphon major. Manag Biol Invasion 9:259-265
Cuthbert RN, Crane K, Dick JTA, Caffrey JM, MacIsaac HJ, Coughlan NE (2018b) Die hard: impact of aquatic disinfectants on the survival and viability of invasive Elodea nuttallii. Aquat Bot 154:11-17

De Ventura L, Weissert N, Tobias R, Kopp K, Jokela J (2016) Overland transport of recreational boats as a spreading vector of zebra mussel Dreissena polymorpha. Biol Invasions 18:1451-1466

Dudgeon D, Arthington AH, Gessner MO, Kawabata Z-I, Knowler DJ, Lévêque C, Naiman RJ, Prieur-Richard A-H, Soto D, Stiassny MLJ, Sullivan CA (2006) Freshwater biodiversity: importance, threats, status and conservation challenges. Biol Rev 81:163-182

Evans CA, Kelting DL, Forrest KM, Steblen LE (2011) Fragment viability and rootlet formation in Eurasian watermilfoil after desiccation. J Aquat Plant Manag 48:57-62

Gallardo B, Aldridge DC (2013) The 'dirty dozen': socio-economic factors amplify the invasion potential of 12 high risk aquatic invasive species in Great Britain and Ireland. J Appl Ecol 50:757-766

Green AJ (2016) The importance of waterbirds as an overlooked pathway of invasion for alien species. Divers Distrib 22:239-247

Heidbüchel P, Kuntz K, Hussner A (2016) Alien aquatic plants do not have higher fragmentation rates than native species-a field study from the River Erft. Aquat Sci 78:767-777

Hoffmann MA, Raeder U, Melzer A (2014) Influence of environmental conditions on the regenerative capacity and the survivability of Elodea nuttallii fragments. J Limnol 74(1):12-20

Hussner A, Stiers I, Verhofstad MJJM, Bakker ES, Grutters BMC, Haury J, van Valkenburg JLCH, Brundu G, Newman J, Clayton JS, Anderson LWJ, Hofstra D (2017) Management and control methods of invasive alien aquatic plants: a review. Aquat Bot 136:112-137

Jiang J, An S, Zhou C, Guan B, Sun Z, Cai Y, Liu F (2009) Fragment propagation and colonization ability enhanced and varied at node level after escaping from apical dominance in submerged macrophytes. J Integr Plant Biol 51:308-315

Johnson LE, Ricciardi A, Carlton JT (2001) Overland dispersal of aquatic invasive species: a risk assessment of transient recreational boating. Ecol Appl 11:1789-1799

Kolar CS, Lodge DM (2001) Progress in invasion biology: predicting invaders. Trends Ecol Evol 16:199-204

Kuntz K, Heidbüchel P, Hussner A (2014) Effects of water nutrients on regeneration capacity of submerged aquatic plant fragments. Ann Limnol 50:155-162

Lafontaine R-M, Beudels-Jamar RC, Delsinne T, Robert H (2013) Risk analysis of the curly waterweed Lagarosiphon major (Ridley) Moss. - risk analysis report of non-native organisms in Belgium from the Royal Belgian Institute of Natural Sciences for the Federal Public Service Health, Food Chain Safety and Environment, p 57

Li F, Zhu L, Xie Y, Jiang L, Chen X, Deng Z, Pan B (2015) Colonization by fragments of the submerged macrophyte Myriophyllum spicatum under different sediment type and density conditions. Sci Rep 5:11821. https://doi.org/10. 1038/srep11821 
Peters K, Sink K, Robinson TB (2017) Raising the flag on marine alien fouling species. Manag Biol Invasion 8:1-11

Piria M, Copp GH, Dick JTA, Duplić A, Groom Q, Jelić D, Lucy FE, Roy HE, Sarat E, Simonović P, Tomljanović T, Tricarico E, Weinlander M, Adámek Z, Bedolfe S, Coughlan NE, Davis E, Dobrzycka-Krahel A, Grgić Z, Kırankaya ŞG, Ekmekçi FG, Lajtner J, Lukas JAY, Koutsikos N, Mennen GJ, Mitić B, Pastorino P, Ruokonen TJ, Skóra ME, Smith ERC, Šprem N, Tarkan AS, Treer T, Vardakas L, Vehanen T, Vilizzi L, Zanella D, Caffrey JM (2017) Tackling invasive alien species in Europe II: threats and opportunities until 2020. Manag Biol Invasion 8:273-286

Price SJ, Ariel E, Maclaine A, Rosa GM, Gray MJ, Brunner JL, Garner TWJ (2017) From fish to frogs and beyond: impact and host range of emergent ranaviruses. Virology 511:272-279

R Core Team (2017) R: A language and environment for statistical computing. R Foundation for Statistical Computing, Vienna

Rask AM, Kristoffersen P (2007) A review of non-chemical weed control on hard surfaces. Weed Res 47:370-380

Redekop P, Hofstra D, Hussner A (2016) Elodea canadensis shows a higher dispersal capacity via fragmentation than Egeria densa and Lagarosiphon major. Aquat Bot 130:45-49

Riis T, Madsen TV, Sennels RSH (2009) Regeneration, colonisation and growth rates of allofragments in four common stream plants. Aquat Bot 90:209-212

Rothlisberger JD, Chadderton WL, McNulty J, Lodge DM (2010) Aquatic invasive species transport via trailered boats: what is being moved, who is moving it, and what can be done. Fisheries 35:121-132

Sandodden R, Brazier M, Sandvik M, Moen A, Wist A-N, Adolfsen P (2018) Eradication of Gyrodactylus salaris infested Atlantic salmon (Salmo salar) in the Rauma River, Norway, using rotenone. Manag Biol Invasion 9:67-77

Santamaría L (2002) Why are most aquatic plants widely distributed? dispersal, clonal growth and small-scale heterogeneity in a stressful environment. Acta Oecol 23:137-154

Sebire M, Rimmer G, Hicks R, Parker SJ, Stebbing PD (2018) A preliminary investigation into biosecurity treatments to manage the invasive killer shrimp (Dikerogammarus villosus). Manag Biol Invasion 9(2):101-113

Shannon C, Quinn CH, Stebbing PD, Hassall C, Dunn AM (2018) The practical application of hot water to reduce the introduction and spread of aquatic invasive alien species. Manag Biol Invasion 9:417-423

Simberloff D, Martin J, Genovesi P, Maris V, Wardle DA, Aronson J, Courchamp F, Galil B, García-Berthou E, Pascal M (2013) Impacts of biological invasions: what's what and the way forward. Trends Ecol Evol 28:58-66

Sutcliffe C, Quinn CH, Shannon C, Glover A, Dunn AM (2018) Exploring the attitudes to and uptake of biosecurity practices for invasive non-native species: views amongst stakeholder organisations working in UK natural environments. Biol Invasions 20:399-411

Svoboda J, Mrugała A, Kozubíková-Balcarová E, Petrusek A (2017) Hosts and transmission of the crayfish plague pathogen Aphanomyces astaci: a review. J Fish Dis 40:127-140

Umetsu CA, Evangelista HBA, Thomaz SM (2012) The colonization, regeneration, and growth rates of macrophytes from fragments: a comparison between exotic and native submerged aquatic species. Aquat Ecol 46:443-449

Williams F, Eschen R, Harris A, Djeddour D, Pratt C, Shaw RS, Murphy ST (2010) The economic cost of invasive nonnative species on Great Britain. CABI Proj No VM10066, $199 \mathrm{pp}$ 